\title{
Managing Justly Across Cultures: The Problem of Fairness in International Business
}

\author{
Rolf D. Dixon (Corresponding author) \\ Weber State University \\ 3802 University Circle, Ogden, Utah 84408, USA \\ Tel: +1-(801)-626-7542Ｅ-mail: rddixon@weber.edu \\ Cam Caldwell \\ University of Georgia \\ G-2 Brooks Hall, Athens, GA 30602-6256, USA \\ Tel: +1-(318)-446-0129Ｅ-mail: camcaldw@uga.edu \\ Apichai Chatchutimakorn \\ College of Business, McNeese State University \\ Kayla Gradney \\ College of Business, McNeese State University \\ Kochakan Rattanametangkul \\ McNeese State University \\ katekochakan@yahoo.com
}

Received: September 14, $2010 \quad$ Accepted: September 29, $2010 \quad$ doi:10.5430/jms.v1n1p22

\begin{abstract}
The aim of this paper is to examine the relationships between organizational justice and the factors that characterize cultural differences. This paper begins by briefly summarizing the nature of organizational justice and by identifying how justice is perceived. Hofstede's five factors of cultural dimension model, which he developed in his seminal 1980 research on national cultures, is utilized to present characteristics of cultural differences. Ten propositions are then offered which relate to organizational justice and differences in cultural perspectives. These propositions suggest specific management approaches that organizational leaders can adopt to be more effective in dealing with employees from respective cultures. This paper concludes by identifying the importance of understanding the relationship between organizational justice and national culture and suggests research opportunities of benefit to both scholars and practitioners.
\end{abstract}

Keywords: Organizational justice, Cultural differences, Organizational fairness

\section{Introduction}

In a business world that has become both increasingly complex and globally competitive (Cameron, 2003; Dowling, Festing \& Engle, 2009), a growing body of evidence suggests that organizational leaders who treat employees with fairness, integrity, and sensitivity are more likely to find that those employees respond with increased commitment and productivity (Senge, 2006; Pfeffer, 1998). Managing the work force in a global society requires leaders to be responsive to employee well-being, job satisfaction, and employee commitment and to create organizational systems that are welcoming, inclusive, and congruent (Findler, Wind, \& Mor Barak, 2007; Cox, 2001). As leaders create and maintain relationships and establish policies to guide employees, the actions of those leaders determine the perceptions of employees about organizational justice (Tyler, Boechmann, \& Huo, 1997). Yet, as Sen (2009) has noted, justice is not 
only a cognitive construct but one that is affective and highly personal.

In Hofstede's (1980) seminal research about national culture, the key values and perspectives that characterize residents of different nations help explain 1) why those people respond in predictable ways, and 2) why it is important for organizational leaders to understand those responses in relating to the residents of each nation. The purpose of this paper is to examine the relationships between organizational justice and the factors that characterize cultural differences. We begin this paper by briefly summarizing the nature of organizational justice and by identifying how justice is perceived. We then explain the framework of Hofstede's five factors (1980); individual vs. collectivism, masculinity vs. femininity, uncertainty avoidance, power distance, and Confucian dynamism, as characteristic of national cultures and also present information about each of these five factors. We offer ten propositions about organizational justice that relate to differences in cultural perspectives. We conclude by identifying the importance of understanding the relationships between organizational justice and national culture and suggest research opportunities of benefit to both scholars and practitioners.

\section{The Nature of Organizational Justice}

Rawls (1971, p.3) called justice "the first virtue of social institutions," established to protect the rights and freedoms of individuals in society and essential for the creation of a cooperative society. According to Morris and colleagues (1999), the principle of organizational justice begins with the notion that rewards should be proportional to contributions, but justice is far more complex than simply articulating the distribution of resources (Luo, 2007; Primeaux, Karri, \& Caldwell, 2003). Scholars frequently note that there are three core dimensions or types of justice: distributive justice, procedural justice, and interactional justice (Luo, 2007; Cropanzano, Bowen, \& Gilliland, 2007; Ambrose \& Amaud, 2005).

The interaction between distributive, procedural, and interactional justice has been well documented in justice literature. Clemmer (1993, p.202) found that procedural and interactional justice "each contributed uniquely to customers' satisfaction." Konovsky and Cropanzano (1991) reported a 0.62 correlation between procedural and interactional justice and a 0.53 correlation between procedural and distributive justice. Masterson and colleagues (2000) also found that interactional justice directly and positively affected perceptions of the quality of leader-member exchange, and procedural justice affected perceptions of organizational support. Evidence suggests that the three components of justice interact, even when this interaction may vary (Cropanzano, Slaughter, \& Bachiochi, 2005).

\section{Distributive Justice}

Distributive justice involves how an organization disburses its resources as it achieves desired outcomes and acknowledges that individuals may not always be treated alike (Ambrose \& Schminke, 2007). Three widely recognized rules of distributive justice are equality, equity, and need (Fortin \& Fellenz, 2008). Equality treats each individual the same; equity rewards individuals proportional to their contribution to desired outcomes; and need distributes resources based on perceived requirements associated with individuals involved (Primeaux, et al., 2003).

Resources or rewards in distributive justice are apportioned based upon an implicit or explicit set of rules, and group members traditionally think of themselves as shareholders in a group or community (Cropanzano, et al., 2007, p.37-38). Greenberg (2001, p.370) explained that "people across many different cultures agree that distributive justice is important although they define justice differently in practice and can favor one rule (equality, equity, need) over another when allocating rewards". Distributive justice implicitly consists of a subjective perception regarding the fairness of how resources are assigned, as each party interprets values, priorities, and duties owed through an individual lens (Fortin \& Fellenz, 2008).

\section{Procedural Justice}

Procedural justice addresses "the means by which outcomes are allocated" (Cropanzano, et al. 2007, p.38). The degree to which procedures, policies, and rules are articulated fairly and followed consistently are also critical to obtaining cooperative behavior (Fuller \& Hester, 2007; Tyler, 1999). Leventhal and colleagues (1980) observed that a process is perceived as procedurally just if it is consistently applied, free from bias in implementation, factually accurate, relevant to the needs of affected stakeholders, correctable, and consistent with an organization's ethical norms. Procedural fairness builds organizational trust and increases individual commitment (Lemons \& Jones, 2001). Fischer and Smith (2006) noted that paying attention to procedural justice issues seems more crucial for managers because "greater perceived justice of organizational procedures was associated with higher satisfaction [and] greater commitment to the organization."

In his seminal research, Blau (1964) noted that perceptions of fairness were based upon elements of the social exchange relationship and were fundamental to the decision to cooperate. Colquitt and colleagues (2001) called procedural justice 
a rational process which incorporates several context-based determinants. When organizational systems are perceived as procedurally fair, participants may accept distributive justice decisions that are personally unfavorable (Kim \& Mauborgne, 2005; Tyler et al., 1997).

\section{Interactional Justice}

Interactional Justice involves the "quality of interpersonal treatment" (Bies \& Moag, 1986, p.44) that people receive in a relationship, and incorporates 1) the degree to which a person is treated with dignity and respect, 2) courtesy shown in interpersonal dealings, and 3) whether a person is provided a personal explanation when treated in a way perceived as unfair (Colquitt, Conlon, Wesson, Porter, \& Ng, 2001; Primeaux, et al., 2003). Reflecting the social exchange perspective (Blau, 1964), people expect fair, honest, courteous, and truthful treatment in their relationships with others (Ladebo, Awotunde, \& AbdulSalaam-Saghir, 2008). Donaldson and Dunfee (1999) have noted that the pursuit of fair and just outcomes is a universal hypernorm that transcend ethical and cultural perspectives but that is highly subjective. Employees who perceive fair treatments by authorities are more likely to evidence high commitment to the values and goals of the organization (Cohen-Charash \& Spector, 2001). Empirical studies have confirmed the independent nature of interactional justice as a moderator of justice perceptions (Scandura, 1999: Bies \& Moag, 1986; Clemmer, 1993).

Summarizing findings of the justice literature Caldwell and colleagues (2001) noted that justice incorporated six fundamental assumptions:

(1) Justice's key components are distributive, procedural, and interactional;

(2) Just treatment leads to the cooperation of others, including their relinquishing of authority and control to those perceived as just;

(3) Justice implies a distinct social contract, incorporating an exchange relationship, equality of rights, or a presumed need;

(4) Perceived ethical duties owed from those in authority are based upon an explicit or implicit duty to behave consistently with roles, responsibilities, and ground rules;

5) Those who relinquish authority or control expect that their interests will be considered and balanced with the long-term collective welfare of other stakeholders;

(6) Justice is contextually sensitive and is merited based upon a composite of internal and external environmental factors.

Each of these six factors confirms the subjective nature of justice as an individualized perception viewed through each person's mediating lens (Primeaux, et al., 2003). Cropanzano and colleagues (2007, p.34) stated "organizational justice has the potential to create powerful benefits for organizations and employees alike [including] greater trust and commitment, improved job performance, more helpful citizenship behaviors, improved customer satisfaction, and diminished conflict." People perceive justice through their perception based on their norms and values (Greenberg, 1993) and view justice as a social contract (Donaldson and Dunfee, 1999). Justice is ultimately a concept (Fortin \& Fellenz, 2008) that is evaluated through the subjective lens of each individual (Primeaux, et al, 2003) and is based upon inferences drawn by each person about the elements of the social contract existing between that individual and another party (Nussbaum, 2004; Hosmer, 2007).

\section{Hofstede's Five-Factor Framework for Describing Culture}

Culture in an international context has been defined as "the collective programming of the mind that distinguishes the members of one group or category of people from another" (Hofstede, 1999, p.35). Culture incorporates the norms, values, and attitudes that reflect shared meaning and patterned ways in which people interact (Litvin, Crotts, and Hefner, 2004, p.30). Cultural typing is considered to be "relatively static" (MacNab \& Worthley, 2000) and a central, enduring, and distinctive part of the identity of groups (Albert \& Whetten, 1985). Hofstede and colleagues (1990) provided a well recognized and frequently cited framework for classifying international cultures that identified five dimensions which explain how people respond to their internal and external environments (Ailon, 2008):

(1) Individualism versus Collectivism - This dimension focused on the relationship between individuals. Individualistic societies value individual achievement, and freedom and ties between individuals were comparatively loose. Collectivistic societies value group relationships, and the achievement of goals tends to be focused upon group-oriented achievements rather than upon individual accomplishments. 
(2) Masculinity versus Femininity - This dimension focused on the relationship between gender and work roles. Masculine cultures sharply differentiate work roles and values such as achievement and the effective exercise of power. Feminine cultures make little differentiation between roles based upon gender.

(3) Uncertainty Avoidance - This dimension reflects the degree of comfort that people feel in unstructured situations and the efforts that they make to control external factors. Uncertainty avoidance reflects the extent to which cultures socialize their members into tolerating uncertainty and ambiguous situations. Members of cultures with high uncertainty avoidance have a strong need for rules and regulations. These cultures prefer clear and detailed instructions and value job security and stable career patterns. Cultures with low uncertainty avoidance are more willing to take risks and are more comfortable with both change and ambiguity.

(4) Power Distance - This dimension focused on the extent to which people are unequal in physical and intellectual capabilities. High power-distance cultures give emphasis to inequalities in role, power, and wealth. Low power-distance cultures tend to play down the importance of status and roles.

(5) Confucian Dynamism - This dimension emphasizes attitudes toward time, respect for tradition, the protection of face, and the reciprocation of gifts and favors. These values are derived from Confucian teachings. Cultures high in this dimension have a high regard for tradition and accompanying high expectations about the formalities expected in social settings.

Hofstede and colleagues (1990) have noted that the variation within cultural groups is often broader than the variation between groups for these five dimensions, but nonetheless have advocated this five-factor model as a useful framework for understanding differences in the way people see the world and determine their priorities.

\section{Organizational Justice and Cultural Perspectives}

The perception of justice cannot be considered complete without understanding difference in national culture (Greenburg, 2001). To illustrate, justice is assessed by individuals whereas inferences about justice can be made by either individuals or organizations (Primeaux, et al., 2003; van Olffen, \& de Cremer, 2007). The three dimensions of justice are said to be positively related to trust and the degree of personal commitment that people show toward the organization (Tzafrir, \& Eitam-Meilik, 2005). Organ (1988, p.64-67) suggested that perceived fairness was an important factor that determined whether an organization's employees would engage in extra role behaviors and opined that justice was often perceived as a moral issue.

Chen and colleagues (1998) suggested that the degree to which employees are willing to engage in extra role behavior is dependent upon whether those employees believe that their supervisor has violated the implicit psychological contract between the organization and the employee. Hosmer (2007) defined the perceived fairness of social contracts as a fundamental ethical principle upon which human relations is established. Othman and colleagues (2005) have also identified the close relationship between employee commitment and perceptions about justice with regard to the employment relationship and the psychological contract. We present ten propositions which clarify the relationship between organizational justice and international cultures.

Olffen (2007) reported that organizational justice, especially procedural and interactional justice, is believed to induce the formation of social exchange relationships in which perceived justice is reciprocated with favorable individual attitudes and behaviors. In other words, organizations considered to be fair are attractive to employees and will motivate them to stay committed (Olffen, 2007). According to Thompson and Heron (2005, p.397), "the highest levels of commitment are reported when there are high levels of both interactional and procedural justice."

A research study by Caldwell, Clapham, and Proctor (2003) found that for MBA students perceptions about procedural and interactional justice in organizations were closely related to perceptions about perceived trustworthiness and affected the willingness of individuals to trust other parties. Kim (2007) found that both organizational structures and the nature of internal communications substantially impacted perceptions about fairness in Korean organizations. Schminke and colleagues (2000) suggested that elements of organizational structure helped contribute to perceptions about procedural fairness. Muller and Lee (2000) noted that the role and quality of communication between the leader and associates substantially influenced perceptions of both trust and justice - impacting both perceptions about interpersonal relationships and organizational fairness. Consistent with this summary of the role of interactional and procedural justice, we offer our first two propositions.

P1: Employees of all cultural backgrounds will respond to a management approach characterized by high levels of interactional and procedural justice with higher levels of employee commitment than employees in organizations characterized by low levels of interactional and procedural justice. 
P2: Employees of all cultural backgrounds will respond to a management approach characterized by high levels of interactional and procedural justice with higher levels of trust than employees in organizations characterized by low levels of interactional and procedural justice.

Principles of justice that are consistent with cultural values are likely to be more acceptable and to be perceived as more just than principles that represent conflicting values (Birnbaum-More \& Wong, 1995). Hofstede's (1980) individualism/collectivism element is among the most common dimension used by researchers to understand the differences between American culture and other cultures (Triandis, 1994). In an individualistic society, people tend to emphasize their own goals over those of their clan or group (Ramamoorthy \& Carroll, 1998; Ramamoorthy, Gupta, Sardessai, \& Flood, 2005). People in individualistic cultures are more likely to focus on self-interests, whereas in collectivist cultures, individuals belong to groups that look after them in exchange for loyalty (Soares, Farhangmehr, \& Shoham, 2007). Furthermore, in an individualistic society, individual goals may or may not be consistent with in-group goals (Triandis, 1994).

Sullivan and colleagues (2003) found that individualism and collectivism orientations impacted the nature of interpersonal relationships in organizations. Lam and colleagues (2002) suggested that individualism and collectivism impacted both perceptions of fairness and willingness to engage in extra-role behaviors. Yamaguchi (2005) determined that for Japanese workers factors of both interactional and procedural justice affected employee willingness to cooperate and perform extra-role behaviors. Anderson and Patterson (2008) found that persons who had a concern for others, typified by a collectivist orientation, were as concerned about issues of equitable distributive justice and procedural justice as persons with a more self-interested individualist orientation. Consistent with these research studies, we suggest the following proposition.

P3: In cultures characterized by high levels of interactional justice and procedural justice, the levels of commitment to engage in extra-role behaviors for individualistic cultures will be no greater than organizations which have collectivist cultures.

Uncertainty avoidance measures the extent which people feel threatened by "uncertain or unknown situations" and is mitigated by explicit and clear rules (Hofstede, 1991, p.13). As a factor reflecting the comfort level that a culture feels with ambiguity and change, uncertainty avoidance is potentially the most significant cultural dimension in international settings (Litvin, et al., 2004, p.30-31). Employees from cultures low in uncertainty avoidance tend to be more tolerant of change and are willing to engage in activities that are perceived as unique or different (Hofstede, 1980). Cultures high in uncertainty avoidance tend to resist change, seek predictability, and attempt to exercise more control by creating rules, laws, and institutions (Primeaux, et al., 2003).

Whetten and Cameron (2007, p.386) suggested that individuals from cultures high in uncertainty avoidance were likely to have a preference for precisely articulated procedural rules to reduce uncertainty and would tend to feel higher levels of trust under circumstances when expectations and ground rules are clearly spelled out. In their explanation of the relationship between transaction costs and cultural differences, Domicone and colleagues (1998) have proposed that spelling out expectations and formalizing agreements in writing would help individuals from cultures high in uncertainty avoidance to reduce uncertainty and would substitute for trust. Fisher and Lovell (2009, p.322-325) have noted that trust, ethics, and justice are closely related constructs that reduce uncertainty and sustain express and implied social contracts. In contrast, individuals from countries lower in uncertainty avoidance are more concerned about relationships that are established than about procedural rules (Domicone, Bracker, \& Shiffler, 1998). Sensitivity to cultural differences is vital in building trust, and creating perceptions about fairness (Michailova \& Hutchings, 2006) and attempting to create trust by focusing on the relationship with individuals high in uncertainty avoidance are likely to communicate a mixed message (Covey, 1992). Consistent with the insights offered by this research about uncertainty avoidance, we propose the following.

P4: Organizations made up of employees from cultures high in uncertainty avoidance will respond to a management approach characterized by high levels of procedural justice with greater levels of trust and cooperative behavior than organizations characterized by low levels of procedural justice.

P5: Organizations made up of employees from cultures which have low levels of uncertainty avoidance will respond to a management approach characterized by high levels of interactional justice with higher levels of trust than organizations characterized by high levels of uncertainty avoidance.

Chiang and Birtch (2007) have noted that cultural background has a distinct impact on how reward preferences are allocated. Kim and colleagues (1990) reported that equity-based reward allocations were culturally influenced and suggested that cultures high in masculinity were also high in their preference for distributive outcomes high in 
consideration of equity regarding contributions. In contrast, Gilligan (1982) had earlier suggested that the feminine perspective about ethical duties was more relationship based, consistent with the perspectives of interactional justice (Bies \& Moag, 1986). Simola (2003) also noted that feminine perspectives are more likely to be concerned with procedural fairness. Masculine cultures, according to Roxas and Stoneback (2004, p.150), are associated with assertiveness, acquisition of material things, and lack of concern for others. The 'gender socialization approach' argues that "males and females have distinctive different values and traits due to gender creating different moral orientations and resulting in different decisions and practices" (Roxas \& Stoneback 2004, p.150). Simga-Mugan and colleagues (2005, p.140) noted that "when facing moral dilemmas, people from Western and masculine cultures utilize ethics of justice while people who are from Eastern and feminine cultures draw upon ethics of care." Based upon this research, we offer two more propositions.

P6: Organizations from cultures which have high levels of masculinity will respond to a managerial approach characterized by high levels of equity-based distributive justice with higher levels of trust than organizations with low levels of masculinity.

P7 Organizations from cultures which have high levels of femininity will respond to a managerial approach characterized by equality-based and need-based distributive justice with higher levels of trust than organizations with low levels of femininity.

Cultures high in Confucian values promote loyalty, respect for authority and harmony and place great value on reciprocity, and interdependence in honoring relationships (Chan, 2008). Hofstede \& Bond (1988) described Confucian dynamism as also incorporating perseverance, face-saving, and long-term orientation. Within the Chinese culture, Schminke and colleagues (2000) noted that at higher levels of the organization issues associated with the ability to allocate resources related to distributive justice were paramount while at lower levels of the organization employees tended to be more concerned with the opportunity to be flexible provided by procedures which do not constrain them. Begley and colleagues (2006) confirmed the findings of Schminke and colleagues also noted that Confucianism's focus on role differentiation at different organizational levels impacted attitudes about trust.

Within a Confucian culture interpersonal relationships are established with superiors, not with the organization -suggesting that managerial commitment can be constructed as a form of reciprocity to a specific person rather than the work organization (Tsui, Schoonhaven, Meyer, Lau, \& Mildovich, 2004, p.140). Piccolo and colleagues (2008, p.273) confirmed that when relationships between leaders and team members were high quality, perceptions about both distributive and procedural justice were also high and led to increased employee commitment. Lau and colleagues (2008) suggested that perceived trustworthiness in Confucian cultures was influenced by demographic similarity and the quality of the relationship between the parties. Consistent with this research about Confucian dynamism, we offer the following proposition.

P8 Organizations from cultures which have high levels of Confucian dynamism will respond to a managerial approach characterized by high procedural and distributive justice with higher levels of trust and extra-role behaviors than organizations with low levels of procedural and distributive justice.

Based on Hofstede's (1980) model, individuals and groups high in power distance more readily accept role and interpersonal inequality and its institutionalization as compared to those with a low power-distance culture, who believe that inequality between people should be minimized (Chow, et al., 2001, p.85). Tyler and colleagues (1997) suggested that individuals low in power distance were less sensitive to variations in procedural justice because they were more likely to accept role differentiations and acquiesce to the authority of supervisors. Subordinates from low power-distance cultures consider themselves to have equal rights to their superiors and expect to be consulted on decisions that affect them (Chow, et al., 2001, p.85). Chow and colleagues (2001, p, 88) also noted that "subordinates of a high power distance culture more readily accept decisions and demands made by their superiors." In contrast, organizations with high power- distance orientations are likely to have role-constrained interactions with their superiors (Lee et al., 2000, p.688).

Lee and colleagues (2000) identified a correlation between low power-distance and individual perceptions about both procedural and distributive justice for Hong Kong employees. Individuals felt both increased trust in their supervisors and higher perceptions of procedural justice and higher levels of contract fulfillment and distributive justice as well (Lee, et al., 2000:685). In assessing the trustworthiness of leaders, van Knippenberg and colleagues (2007:113) found that individual cultural expectations about leader roles, including power- distance perspectives, moderated perceptions of fairness and justice. Henri (2006) had noted that accounting firms that were more flexible and less role dominant tended to use a greater variety of performance measurement methods to focus firm performance and engender employee support. Based upon this research about high power-distance cultures, offer the following two propositions. 
P9: Individuals in organizations who have low levels of power distance will respond to a managerial approach characterized by high levels of equity-based distributive justice and high procedural justice with more trust in supervisors than individuals in organizations who have high levels of power distance.

P10: Individuals in organizations who have low levels of power distance will respond to a managerial approach characterized by high levels of managerial flexibility with more personal commitment than individuals in organizations who have low levels of power distance.

Each of these ten propositions provides opportunities for scholars and practitioners to examine the way that cultural perspectives impact employees view of managerial and organizational factors that reflect employee perceptions about the implicit social contract that exists between the organization and its people (Hosmer, 2007; Rousseau, 1989 \& 1995).

\section{Contributions of Our Paper}

We suggest that our paper and the ten propositions it presents contributes to the ongoing dialogue about organizational justice and its role and impact in international business settings. We affirm the importance of organizational justice as a factor impacting employee trust and commitment and identify the three major categories of justice. This paper affirms the value of Hofstede's five-factor framework in describing factors that reflect cultural differences and explain how differences in culture impact employees. The academic literature clearly supports a relationship between cultural differences and perceptions about management effectiveness and trust in international business settings. (Chow, et al., 2001; Primeaux et al., 2003).

Further, we examine the relationships between organizational justice and the factors identified by Hofstede's research about these differences in international culture. As noted by a multitude of scholars (Dowling, et al., 2009; Hosmer, 2007; Cropanzano, et al., 2007; Ambrose \& Amaud, 2005), perceptions about justice vary based upon the cultural perceptions and backgrounds of individual employees. Recognizing and responding to the differences in individual and cultural perspectives about justice has profound implications for effectively managing employees (Dowling, Festing, \& Engle, 2009).

Finally, we offer ten propositions about organizational justice that relate to differences in cultural perspectives. Citing the scholarly research about the relationships between cultural types and organizational justice, leadership effectiveness, employee commitment, and organizational trustworthiness, we cite dozens of studies that identify the factors that influence individual and group perceptions about individual and organizational justice. These propositions provide a research agenda that should undergo operationalization and empirical study.

\section{Conclusion}

While the discussion presented in this paper is descriptive and the propositions exploratory, it is the intent of the authors to suggest that the ability of organizations to create aligned systems that are perceived as fair and just can substantially contribute to the level of employees' commitment and the extent which employees perform as highly motivated organizational citizens. Understanding justice addresses our ability to achieve outcomes that are rational, morally equitable and freedom enhancing (Sandel, 2009: Chapter 10). We suggest further that justice perceptions are not only assessed on the basis of gender and age, but are substantially impacted by the subjective lens of national culture. Cultural gaps have a huge impact on business because corporate cultures and way of doing things are deeply entrenched. Wise managers who thoroughly understand the cultural factors which impact perceptions about justice will be able to craft organizational policies and practices which enable them to be responsive to the needs of their employees. The ability to provide aligned systems, policies, and practices that facilitate the achievement of the organizational mission and that resonate with employee values is well recognized as a contributor to long-term organizational profitability and strategic competitive advantage. Building trust by managing justly begins by making the effort to truly understand those served by the organization. At the same time, as Hofstede (2009) has more recently noted organizations also must become more just by focusing on society's broader interests, rather than simply the parochial interests of their own organizations.

In the opening lines of his classic text on international culture, Geert Hofstede wisely observed that the survival of mankind will depend to a large extent on its ability to act together to understand how "others" thinking differs from ours. As organizational leaders incorporate insights about justice in dealing with employees in the global marketplace, their understanding of how employees think will impact organizational effectiveness, profitability, and long-term wealth creation. We hope that this paper and propositions offered will lead to further theory development and empirical research on the issue of justice and cross-cultural management. 


\section{References}

Ailon, G. (2008). Mirror, mirror on the wall: Culture's consequences in a value test of its own design. Academy of Management Review, 33 (4), 885-904.

Albert, S., \& Whetten, D. A. (1985). Organizational identity. Research in Organizational Behavior, 7, 263-296.

Ambrose, M. L., \& Amaud, A. (2005). Are procedural justice and distributive justice conceptually distinct? In J. A. Colquitt \& J. Greenberg, (Eds.), Handbook of Organizational Justice, (pp. 85-112) Mahwah, NJ: Lawrence Erlbaum Associates.

Ambrose, M. L., \& Schminke, M. (2007). Examining justice climate: Issues of fit, simplicity, and content. In F. Dansereau \& F. J. Yammarino (Eds.) Research in multilevel issues (Vol. 6, pp. 397-413). Oxford, England: Elsevier.

Anderson, W., \& Patterson, M. (2008). Effects of social value orientations on fairness judgements. Journal of Social Psychology, 148(2), 223-246.

Begley, T. M., Lee, C., \& Hui, C. (2006). Organizational level as a moderator of the relationship between justice perceptions and work-related reactions. Journal of Organizational Behavior, 27(6) 705-721.

Bies, R. J., \& Moag, S. (1986). Interactional justice: Communication criteria of fairness. In R. J. Lewicki, B. M. Sheppard, and M. H. Bazerman (Eds.), Research on Negotiations in Organizations, (Vol. 1, pp. 43-55). Greenwich, CT:JAI.

Birnbaum-More, P. H., \& Wong, G. Y. Y. (1995). Acquisition of managerial values in the People's Republic of China and Hong Kong. Journal of Cross-Cultural Psychology, 25, 255-275.

Blau, P. (1964). Exchange and power in social life. New York: Wiley.

Caldwell, C, J. Campbell \& C. D. Parks. (2001) Trustworthiness and justice - An integrative perspective. Paper presented at the Eighth Annual Conference on Ethics in Business, Chicago, IL.

Caldwell, C., Clapham, S., \& Proctor, G. (2003) Trustworthiness, justice, and the mediating lens: A demographic analysis. Paper presented at the European Academy of Management Conference in Milan, Italy.

Cameron, K. S. (2003). Ethics, virtuousness, and constant change. In N. M. Tichy, and A. R. McGill (Eds.) The ethical challenge: How to lead with unyielding integrity. (185-194), San Francisco, CA: Jossey-Bass.

Chan, G. K. Y. (2008). The Relevance and Value of Confucianism in Contemporary Business Ethics. Journal of Business Ethics, 77(3), 347-360.

Chen, X., Hui, C., \& Sego, D. J. (1998). The role of organizational citizenship behavior in turnover: Conceptualization and preliminary tests of key hypotheses. Journal of Applied Psychology, 83(6), 922-931.

Chiang, F. F. T., \& Birtch, T. (2007). The transferability of management practices: Examining cross-national differences in reward preferences. Human Relations, 60(9), 1293-1330.

Chow, C. W., Lindquist, T. M., \& Wu, A. (2001). National culture and the implementation of high-stretch performance standards: An exploratory study. Behavioral Research in Accounting, 13, 85-109.

Clemmer, E. C. (1993). An investigation into the relationship of fairness and customer satisfaction with services. In R. Cropanzano (Ed.) Justice in the Workplace. Hillsdale, NJ: Lawrence Erlbaum.

Cohen-Charash, Y, \& Spector, P. E. (2001). The role of justice in organizations: A meta-analysis. Organizational Behavior and Human Decision Processes, 86(2), 278-321.

Colquitt, J. A., Conlon, D. E., Wesson, M. J, Porter, C. O. L. H, \& Ng, K. Y. (2001). Justice at the millennium: A meta analytic review of 25 years of justice research. Journal of Applied Psychology, 86(3), 424-445.

Covey, S. R. (1992). Principle centered leadership. New York: Simon \& Schuster.

Cox, T. Jr. (2001). Creating the multicultural organization: A strategy for capturing the power of diversity. San Francisco : Jossey-Bass.

Cropanzano, R., Bowen, D. E., \& Gilliland, S. W. (2007). The Management of Organizational Justice. Academy of Management Perspectives, 21(4), 34-48.

Cropanzano., R., Slaughter, J. E., \& Bachiochi, P. D. (2005). Organizational justice and black applicants' reactions to affirmative action. Journal of Applied Psychology, 90, 1168-1184. 
Domicone, H., Bracker, J., \& Shiffler, R. (1998). Transaction cost economics: A cross-cultural perspective for understanding and communication. Strategic Change, 7(2), 89-99.

Donaldson and Dunfee, (1999). Ties that bind: A social contracts approach to business ethics. Boston, MA:Harvard Business Press.

Dowling, P. J., Festing, M., \& Engle, A. D. (2009) International human resource management (Fifth Edition), Mason, OH: Thomson South-Western.

Findler, L., Wind, L. H., \& Mor Barak, M. E. (2007). The challenge of workforce management in a global society: Modeling the relationship between diversity, inclusion, organizational culture, and mmployee well-being, job satisfaction and organizational commitment. Administration in Social Work, 31(3), 63-94.

Fischer, R., \& Smith, P. (2006). Who cares about justice? The moderating effect of values on the link between organizational justice and work behavior. Applied Psychology. 55(4), 541-562.

Fisher, C., and Lovell, A. (2009). Business ethics and values: Individual, corporate, and international perspectives $\left(3^{\text {rd }}\right.$ edition). New York:Prentice-Hall.

Fortin, M., \& Fellenz, M. (2008). Hypocrocies of fairness: Towards a more reflexive ethical base in organizational justice research and practice. Journal of Business Ethics, 78(3), 415-433.

Fuller, J. B. Jr., \& Hester, K. ( ). Procedural justice and the cooperative worker: An interactional model of union participation. Journal of Labor Research, 28(1), 189-202.

Gilligan, C. (1982). In a different voice. Boston, MA: Harvard University Press.

Greenberg, J. (1993). Studying organizational justice cross-culturally: Fundamental challenges. The International Journal of Conflict Management, 12(4), 365-375.

Henri, J. F. (2006). Organizational culture and performance measurement systems. Accounting, Organizations \& Society, 31(1), 77-103.

Hofstede, G. (2009). Business goals for a new world order: beyond growth, greed, and quarterly results. Asia Pacific Business Review, Vol. 15, Iss. 4, 481- 488.

Hofstede, G. (1991). Cultures and organizations: Software of the mind. London: McGraw Hill.

Hofstede, G. (1980). Culture's consequences. Beverly Hills, CA: Sage Publications.

Hofstede, G., (1999). Problems remain, But theories will change: The universal and the specific in $21^{\text {st }}$-century global management. Organizational Dynamics, 238(1), 34-44.

Hofstede, G., \& Bond, M. H. (1988). The confucius connection: From cultural roots to economic growth. Organizational Dynamics. 16, 5-21.

Hofstede, G., Neuijen, B., Ohayv, D. D., \& Sanders, G. (1990). Measuring organizational cultures: A qualitative and quantitative study across twenty Cases. Administrative Science Quarterly, 35(2), 286-316.

Hosmer, L. T. (2007). The ethics of management (Fifth Edition). New York: McGraw-Hill.

Kim, H. S., (2007). A multilevel study of antecedents and a mediator of employee-organization relationships. Journal of Public Relations Research, 19(2), 167-197.

Kim, W. C., \& Mauborgne, R. A. (2005). Blue ocean strategy: How to create uncontested market space and make competition irrelevant. Cambridge, MA: Harvard Business School Press.

Kim, K. I, Park, H. J., \& Suzuki, N. (1990). Reward allocations in the United States, Japan, and Korea: A comparison of individualistic and collectivistic Cultures. Academy of Journal, 33(1), 188-198.

Konovsky, M. A., \& Cropanzano, R. (1991). Perceived fairness and employee drug testing as a predictor of employee attitudes and job performance. Journal of Applied Psychology, 76, 698-707.

Ladebo, O. J., Awotunde, J. M., \& AbdulSalaam-Saghir, P. (2008). Coworkers' and supervisor interactional justice: Correlates of extension personnel's job satisfaction, distress, and aggressive behavior. Journal of Behavioral \& Applied Management, 9(2), 206-225.

Lam, S., Schaubroeck, J., \& Aryee, S. (2002). Relationship between organizational justice and employee work outcomes: A cross-national study. Journal of Organizational Behavior, 23, 1-18. 
Lau, D., Lam, L., \& Salamon, S. (2008). The impact of relational demographics on perceived managerial trustworthiness: Similarity or norms? The Journal of Social Psychology, 148(2), 187-209.

Lee, C., Pillutla, M., \& Law, K. (2000). Power-distance, gender and organizational justice. Journal of Management, 26(4), 685-704.

Lemons, M.A., \& Jones, C. A., (2001). Procedural justice in promotion decisions: Using perceptions of fairness to build employee commitment. Journal of Managerial Psychology, 16, 268-280.

Leventhal, G. S., Karuza, J., \& Fry, W. R. (1980). Beyond fairness: A theory of allocation preferences. In G. Mikula (Ed.) Justice and Social Interaction. New York: Springer-Verlag.

Litvin, S. W., Crotts, J. C., \& Hefner, F. L. (2004). Cross-cultural tourist behaviour: A replication and extension involving Hofstede's uncertainty avoidance dimension. International Journal of Tourism Research, 6(1), 29-37.

Luo, Y. (2007). The independent and interactive roles of procedural, distributive, and interactional justice in strategic alliances. Academy of Management Journal, 50(3), 644-664.

Masterson, S., Lewis, K., \& Goldman, B. (2000). Integrating justice and social exchange: The differing effects of fair procedures and treatment on work relationships. The Academy of Management Journal, 43(4), 738-748.

Michailova, S., \& Hutchings, K. (2006). National cultural influences on knowledge sharing: A comparison of China and Russia. Journal of Management Studies, 43(3), 383-405.

Morris, Leung, Ames, \& Lickel. (1999). Views from inside and outside: Integrating emic and etic insights about culture and justice judgement. Academy of Management Review, 24(4), 781-796.

Muller, B. H., \& Lee, J. (2000). Leader-member exchange and organizational communication satisfaction in multiple contexts. Journal of Business Communication, 39, 220-243.

Nussbaum, M. C. (2004). Beyond the social contract: Capabilities and global justice. Oxford Development Studies, 32(1), 3-19.

Organ, D. W. (1988). Organizational Citizenship Behavior: The Good Soldier Syndrome. Toronto, Canada: D. C. Heath and Company.

Othman, R., Arshad, R., Hashim, N. A., \& Isa, R. M. G. M. (2005) Psychological contract violation and organizational citizenship behavior. International Journal of Business, 7(3), 325-349.

Piccolo, R. F., Bardes, M., Mayer, D. M., \& Judge, T. A. (2008). Does high quality leader-member exchange accentuate the effects of organizational justice? European Journal of Work \& Organizational Psychology, 17(2), 273-298.

Primeaux, P., Karri, R., \& Caldwell, C. (2003). Cultural insights to justice: A theoretical perspective through a subjective lens. Journal of Business Ethics, 46(2), 187-199.

Ramamoorthy, N., Gupta, A., Sardessai, R. M., \& Flood, P. C. (2005). Individualism/collectivism and attitudes towards human resource systems: A comparative study of American, Irish, and Indian MBA students. International Journal of Human Resource Management, 16(5), 852-869.

Ramamoorthy, N., \& Carroll, S. J. (1998). Individualism-collectivism orientations and reactions toward alternative human resource management practices. Human Relations, 51(5), 571-588.

Rawls, J. (1971). A theory of justice. Cambridge, MA: Belnap Press.

Rousseau, D. M. (1989). Psychological and implied contracts in organizations. Employee Responsibilities and Rights Journal, 2, 121-139.

Rousseau, D. M. (1995) Psychological contracts in organizations. Thousand Oaks, CA: Sage.

Roxas, M. L, \& Stoneback, J. Y. (2004). The importance of gender across cultures in ethical decision-making. Journal of Business Ethics, 50(2), 149-165.

Sandel, M. J., (2009). Justice: What's the right thing to do? New York: Farrar, Straus, and Giroux.

Sen, A., (2009). The idea of justice. Boston, MA:Belknap Press.

Scandura, T. A. (1999). Rethinking leader-member exchange: An organizational justice perspective. Leadership Quarterly, 10(1), 25-40.

Schminke, M., Ambrose, A. L., \& Cropanzano, R. S. (2000). The effect of organizational structure on perceptions of procedural fairness. Journal of Applied Psychology, 85, 294-304. 
Senge, P. M. (2006). The fifth discipline: The art and practice of the learning organization. New York: Doubleday.

Simga-Mugan, C., Daly, B. A., Onkal, D., \& Kavut, L.,(2005). The influence of nationality and gender on ethical sensitivity: An application of the issue-contingent model. Journal of Business Ethics, 57(2), 139-159.

Simola, S. (2003). Ethics of justice and care in corporate crisis management. Journal of Business Ethics, 46(4), 351-361.

Soares, S.; Farhangmehr, M. \& Shoham, A. (2007). Hofstede's dimension of culture in international marketing studies. Journal of Business Research, 60, 277-284.

Sullivan, D. M., Mitchell, M. S., \& Uhl-Bien, M. (2003). The new conduct of business: How LMX can help capitalize on cultural diversity. In G. B. Graen (Ed.), Dealing with diversity: A volume in LMX leadership: The series. (pp. 183-218) Greenwich, CT: Information Age Publishing.

Thompson, M., \& Heron, P. (2005). The difference a manager can make: Organizational justice and knowledge worker commitment. The International Journal of Human Resource Management, 16(3), 383-404.

Triandis, H. C., (1994). Theoretical and methodological approaches to the study of collectivism and individualism. In U. Kim, H. C. Triandis, C. Kagitcibasi, S. Choi, and G. Yoon (Eds.) Individualism and collectivism: Theory, method, and applications. Beverly Hills, CA:Sage.

Tsui, A. S., Schoonhaven, C. B., Meyer, M. W., Lau, C. M., \& Milkovich, G. T. (2004). Organization and management in the midst of societal transformation: The People's Republic of China. Organization Science, 15, 133-144.

Tyler, T. R. (1999). Why people cooperate with organizations: An identity-based perspective. (pp. 201-246), In R. Sutton and B. Staw (Eds.) Research in Organizational Behavior. Stanford, CT: JAI Press.

Tyler, T. R., Boeckmann, R. J., Smith, H. J., \& Huo, Y. J. (1997). Social justice in a diverse society. Oxford: Westview Press.

Tzafrir, S., \& Eitam-Meilik, M. (2005). The impact of downsizing on trust and employee practices in high tech firms: A longitudinal analysis. The Journal of High Technology Management, 16(2), 193-207.

van Knippenberg, D., De Cremer, D., \& van Knippenberg, B. (2007). Leadership and fairness: The state of the art. European Journal of Work \& Organizational Psychology, 16(2), 113-140.

van Olffen, W., \& de Cremer, D. (2007). Who cares about organizational justice? How personality moderates the effects of perceived fairness on organizational attachment. European Journal of Work and Organizational Psychology, 16(4), 386-406.

Whetten, D. A., \& Cameron, K. S. (2007). Developing management skills ( ${ }^{\text {th }}$ Edition). Upper Saddle River, NJ:Prentice-Hall.

Yamaguchi, I. (2005). Interpersonal communication tactics and procedural justice for uncertainty management of

Japanese workers. Journal of Business Communication, 42(2), 168-194. 